\title{
The effects of environmental temperature and plane of nutrition on heat loss, energy retention and deposition of protein and fat in groups of growing pigs
}

\author{
By M. W. A. VERS'TEGEN*, W. H. CLOSE, I. B. START and L. E. MOUNT \\ Agricultural Research Council, Institute of Animal Physiology, Babraham, Cambridge
}

(Received 24 May 1972-Accepted 30 November 1972)

\begin{abstract}
1. Eight groups each of four castrated male pigs, 25-30 kg initial body-weight, were kept for periods of 3 weeks in a calorimeter equipped as a pig pen and maintained at either $8^{\circ}$ or $20^{\circ}$. At each temperature two feeding levels ( $\mathrm{g}$ food $/ \mathrm{kg}$ body-weight per $\mathrm{d}$ ) were used, 45 and 52 at $8^{\circ}$, and 39 and 45 at $20^{\circ}$. Metabolizable energy, heat loss and nitrogen balance were measured.

2. Heat loss was higher at $8^{\circ}$ than at $20^{\circ}$ and was independent of plane of nutrition, whereas at $20^{\circ}$ the higher heat loss occurred at the higher plane of nutrition. Energy retention depended on both temperature and feeding level, and was highest at the $52 \mathrm{~g}$ feeding level at $8^{\circ}$.

3. $\mathrm{N}$ retention was not infuenced by environmental temperature but varied with plane of nutrition (correlation coefficient $=0.94$ ), the increase being $9.98( \pm 0.8) \mathrm{mg} \mathrm{N}$ per $\mathrm{g}$ food increase. The correlation coefficient between $\mathrm{N}$ retention and body-weight gain was also 0.94 ; body. weight gain was correlated with $\mathrm{N}$ retention rather than with fat deposition. Fat gain was reduced at the lower feeding levels and at the lower environmental temperature at the feeding level of $45 \mathrm{~g} / \mathrm{kg}$.

4. The partial efficiency of energy retention at $20^{\circ}$ was $66.5 \%$. From this efficiency the maintenance requirement (at zero energy retention) at $20^{\circ}$ was calculated to be $4 \mathrm{r} 8 \mathrm{~kJ} / \mathrm{kg}^{0.75}$. At $8^{\circ}$ the partial efficiency of energy retention was $99.4 \%$.
\end{abstract}

Calorimetric measurements have shown that, in addition to effects associated with body size and thermal insulation, the rate of an animal's heat loss is determined. principally by two factors, the plane of nutrition and the environmental temperature. The environmental temperature also determines which of these two factors is primary: in the zone of thermal neutrality, the plane of nutrition is the chief determinant, with the higher heat loss occurring at the higher level of feeding, whereas under cooler conditions heat loss is dependent on the environmental temperature and the plane of nutrition has little effect. This relation has been demonstrated for heat production measured by indirect calorimetry in individual clipped sheep (Graham, Wainman, Blaxter \& Armstrong, I959) and in groups of pigs (Verstegen, 1971), and for heat loss measured by direct calorimetry in groups of pigs (Close, Mount \& Start, 1971).

In the direct calorimetric experiments on pigs each group was exposed to two consecutive planes of nutrition while the environmental temperature was held constant. In earlier work (Holmes \& Mount, 1967), each group had been exposed to two consecutive environmental temperatures while the plane of nutrition was held constant. In both instances at the lowest environmental temperatures used $\left(7\right.$ and $9^{\circ}$ respectively) at a given level of food intake the rate of heat loss was increased significantly and the rate of energy retention (metabolizable energy intake less heat loss) reduced correspondingly.

In both sets of experiments on pigs there was the possibility that the results obtained

* On leave from Department of Animal Husbandry, The Agricultural University, Wageningen, The Netherlands. 
in the latter part of each experiment were affected to some degree by the change in feeding level or temperature in the middle of each experiment. A new series of investigations has therefore been made in which each group of pigs has been exposed to the same temperature and the same plane of nutrition throughout each experiment. In addition, and simultaneously with the calorimetric measurements, the partition of energy retention into protein and fat has been determined by measurement of the metabolizable energy intake and the nitrogen balance throughout the course of each experiment.

Usually experiments of this nature have been performed on single animals which are restrained in a metabolism cage and which may have a harness attachment for the collection of faeces and urine. However, as has been shown by Holmes (1966), Livingston, Fuller \& Livingstone (1969), Close (1970) and Verstegen (1971), animals kept individually react differently from those kept in groups, especially under cold conditions. Groups of pigs have been used in the present study to make the conditions more closely comparable with those of the animals' usual mode of existence.

\section{MATERIALS AND METHODS}

\section{Animals}

The animals were selected for experiment from the Large White herd which is maintained free of enzootic pneumonia on the Institute farm. The piglets were all male, castrated at 3 weeks and weaned when 6 weeks old; they had access to creep feed from I week of age. The animals used weighed $24-28 \mathrm{~kg}$ at the start of the experiment and $35-45 \mathrm{~kg}$ at the end. Thorbek (1969) has shown that $\mathrm{N}$ retention is greatest in the weight range $20-50 \mathrm{~kg}$ body-weight, which includes the range in the present experiments.

\section{Plan of experiments}

Two series of experiments were carried out in a large heat sink calorimeter equipped as a pig pen (Mount, Holmes, Start \& Legge, 1967). For each experiment four castrated males were selected on the basis of litter of origin, weight and growth rate as described for previous experiments (Holmes $\&$ Mount, 1967). Eight experiments were carried out with duplicated levels of feeding at each of the environmental temperatures $8^{\circ}$ and $20^{\circ}$. Previous experiments (Close et al. 1971) have shown $8^{\circ}$ and $20^{\circ}$ to be respectively below and within the zone of thermal neutrality for groups of pigs of the weights and at the feeding levels used in these experiments.

In each experiment the animals were introduced into the calorimeter on a Monday and remained there for 3 weeks. The animals had been previously exposed to the calorimeter temperature for about 5 weeks and no difficulties were experienced with habituation. Heat loss was measured continuously (except for cleaning periods), beginning on the first Friday, by the method described by Holmes \& Mount (1967). The calorimeter was cleaned out on Monday, Wednesday and Friday of each week, when the animals were weighed and their rectal temperature was measured. 
Table r. Composition of the food ( $\mathrm{g} / \mathrm{kg}$ dry matter); the food contained I I $\mathrm{g}$ water $/ \mathrm{kg}$

\begin{tabular}{|c|c|c|c|c|}
\hline \multicolumn{2}{|c|}{ Ingredient } & Chemical composition & Mean & SE \\
\hline Barley meal & 45 & Crude protein & $20 \cdot 2$ & 0.27 \\
\hline Wheat meal & Io & Crude fibre & $4 \cdot 59$ & I'I I \\
\hline Wheatings & 24 & Ether extract & $3 \cdot 1$ & 0.09 \\
\hline Flaked maize & 4 & Ash & $7 \cdot 3$ & 0.14 \\
\hline Soya-bean meal & 4 & Silica & 0.32 & 0.09 \\
\hline Fish meal & 4 & Calcium & $I \cdot 48$ & 0.17 \\
\hline Meat meal & 4 & Phosphorus & 0.91 & 0.01 \\
\hline Yeast & I & Potassium & 0.93 & 0.09 \\
\hline Grass meal & $2 \cdot 5$ & Magnesium & 0.24 & 0.04 \\
\hline Vitamins and minerals & $\mathrm{I} \cdot \mathbf{2 5}$ & Sodium & 0.28 & 0.07 \\
\hline Spice & 0.25 & Chloride & 0.36 & 0.06 \\
\hline & & $\left.\begin{array}{l}\text { Manganese } \\
\text { Zinc }\end{array}\right\} \begin{array}{l}\text { (mg/kg dry } \\
\text { matter) }\end{array}$ & $\begin{array}{r}90 \\
138 \\
27\end{array}$ & $\begin{array}{l}3 \cdot 3 \\
6 \cdot 5\end{array}$ \\
\hline
\end{tabular}

\section{Feeding}

The animals were fed on a commercial 'growers' diet which was analysed weekly throughout each experiment; the ingredient composition and mean analysis are given in Table $\mathrm{I}$. The planes of nutrition adopted were 45 and $5^{2} \mathrm{~g}$ food/kg body-weight per $\mathrm{d}$ at $8^{\circ}$, and 39 and $45 \mathrm{~g}$ food $/ \mathrm{kg}$ body-weight per $\mathrm{d}$ at $20^{\circ}$. These quantities were chosen because previous experiments (Close et al. I97 I) had suggested that the energy retentions of groups of pigs on the 45 and $52 \mathrm{~g}$ feeding levels at $7^{\circ}$ corresponded approximately with those on the 39 and $45 \mathrm{~g}$ feeding levels at $20^{\circ}$. The food was offered dry in pelleted form in equal lots twice daily at 09.00 and 17.00 hours. The calorimeter was equipped with a constant-level water-bowl supplied from a tank in the calorimeter shell-space and the consumption of water during each $24 \mathrm{~h}$ period was recorded from a float in the tank. Water and food were both kept at the same temperature as that of the calorimeter.

On $3 \mathrm{~d}$ of each week the amount of food to be offered within each weighing period was calculated on the basis of expected gain in weight. To reduce its activity at weighing each animal was given an additional $100 \mathrm{~g}$ food, which was included in the calculation of energy balance. The food which was spilt by the animals was collected and weighed, and then deep-frozen until the end of the experiment when it was analysed. The experiments were carried out between May 197 I and January 1972; the order of the experiments is given in Table 2, together with the mean ages and bodyweights of the animals at the beginning and end of the calorimeter periods, the levels of feeding employed and the temperatures used in the calorimeter.

\section{Heat loss}

The calorimeter was of the direct type and the non-evaporative heat output of the animals was recorded from an automatically operated heat sink in the calorimeter. The evaporative component of heat loss was recorded from the wet- and dry-bulb temperatures of the inlet and exhaust air. At $8^{\circ}$, when the temperature of the heat sink was occasionally below the dew-point of the air circulating within the chamber, conden- 
Table 2. Ages and body-weights of the pigs (four per experiment), plane of nutrition and calorimeter conditions

\begin{tabular}{|c|c|c|c|c|c|c|c|}
\hline \multirow[b]{2}{*}{$\begin{array}{l}\text { Expt } \\
\text { no. }\end{array}$} & \multirow[b]{2}{*}{$\begin{array}{c}\text { Date of } \\
\text { experiment }\end{array}$} & \multirow{2}{*}{$\begin{array}{c}\text { Feeding } \\
\text { level } \\
\text { (g/kg } \\
\text { body-wt } \\
\text { per d) }\end{array}$} & \multirow[b]{2}{*}{$\begin{array}{c}\text { Age at } \\
\text { beginning } \\
\text { (weeks) }\end{array}$} & \multirow{2}{*}{$\begin{array}{c}\text { Initial } \\
\text { mean } \\
\text { body-wt } \\
(\mathrm{kg})\end{array}$} & \multirow{2}{*}{$\begin{array}{c}\text { Final } \\
\text { mean } \\
\text { body-wt } \\
(\mathrm{kg})\end{array}$} & \multicolumn{2}{|c|}{ Calorimeter conditions } \\
\hline & & & & & & $\begin{array}{c}\text { Temperature } \\
\left({ }^{\circ} \mathrm{C}\right)\end{array}$ & $\begin{array}{c}\text { Relative } \\
\text { humidity }(\%)\end{array}$ \\
\hline I & May I97I & 45 & I3 & $24 \cdot 6$ & $34 \cdot 5$ & 20 & 76 \\
\hline 2 & June I97 I & 39 & 12 & 25.8 & $35 \cdot 0$ & 20 & 86 \\
\hline 3 & July I97I & 52 & 13 & $27 \cdot 8$ & $42 \cdot 0$ & 8 & 89 \\
\hline 4 & Aug. I97I & 45 & I4 & $27 \cdot 6$ & $39 \cdot I$ & 8 & $9 I$ \\
\hline 5 & Sept. I97I & 45 & 12 & $24 \cdot 5$ & 35.4 & 8 & 89 \\
\hline 6 & Oct. I971 & 52 & $I_{3}$ & $23 \cdot 1$ & $32 \cdot 7$ & 8 & 90 \\
\hline 7 & Nov. 1971 & 39 & $I_{4}$ & $24^{*} 9$ & $35 \cdot 6$ & 20 & 66 \\
\hline 8 & Jan. I972 & 45 & I 3 & $26 \cdot 0$ & $37 \cdot 5$ & 20 & 67 \\
\hline
\end{tabular}

sate was formed on the surface of the heat sink unit. The condensate was collected and weighed. The ventilation rate through the chamber was between 50000 and 60000 $1 / \mathrm{h}$, measured by a rotameter and maintained by a centrifugal pump.

On the days on which the pen calorimeter was cleaned out it was not possible to obtain a record of heat loss in the calorimeter during the whole $24 \mathrm{~h}$ period as recording was not begun until ${ }_{5} 5.00$ hours. Heat loss on these days was calculated as the mean of the heat losses on the day previous to and the day following weighing, corrected for the additional food given during weighing and assuming for this food an efficiency of $70 \%$ conversion of metabolizable energy into energy retention.

\section{$N$ balance periods and sampling techniques}

Each experiment was divided into seven periods by the cleaning-out days in the calorimeter. There were, therefore, a total of three periods each of $3 \mathrm{~d}$ duration (Friday to Monday) and four periods each of $2 \mathrm{~d}$ duration (Monday to Wednesday and Wednesday to Friday). 'The Friday of the week in which the animals were introduced into the calorimeter was taken as the beginning of period $\mathrm{I}$, so that periods $\mathrm{I}, 4$ and 7 were each of $3 \mathrm{~d}$ duration and periods $2,3,5$ and 6 each of $2 \mathrm{~d}$ duration.

In each period faeces and urine were collected. The floor area of the calorimeter was covered with removable hardwood slats raised $25 \mathrm{~mm}$ above the floor; this facilitated drainage, cleaning and collection. The floor of the calorimeter was so arranged that urine voided by the animals flowed continuously into a drain and was collected in a large receptacle containing $100 \mathrm{ml} \mathrm{H}_{2} \mathrm{SO}_{4}(460 \mathrm{~g} / 1$ ). Faeces were collected from the wooden slats and the floor on each cleaning morning. The slats were thoroughly scraped to remove as much solid faeces as possible. They were then washed with water, the volume of water at each washing varying between 20 and 401 . When all faeces had been removed from the calorimeter, the floor area was washed with slightly acidified water. All washings were collected and analysed.

At the end of each period the collected faeces, urine and washings were each separately thoroughly mixed and samples taken for $\mathrm{N}$ and dry-matter determinations.

The losses of ammonia into the calorimeter atmosphere were measured by continuously drawing samples of the inlet and exhaust air through saturator bottles ( $125 \mathrm{ml}$ 
capacity) containing a known amount of acid ( $\left.30 \mathrm{ml} 0.05 \mathrm{M}-\mathrm{H}_{2} \mathrm{SO}_{4}\right)$. The rates of flow were in the region of $\mathrm{I} 1 / \mathrm{min}$ and were maintained by capillary tube connection to a vacuum pump. The inlet and exhaust air flows were measured by a wet gas-meter inserted in line after each bottle. After each experimental period the bottles were disconnected from the system and the gas-meters read. The contents of each bottle were titrated against $\mathrm{O} \cdot \mathrm{I} \mathrm{M}-\mathrm{NaOH}$ with bromocresol green and methyl red as indicator, and it was assumed that all the titratable base was $\mathrm{NH}_{3}$.

The following is an example of the calculation (ventilation rate through pen: $5 \mathrm{I} 000$ $1 / \mathrm{h})$ :

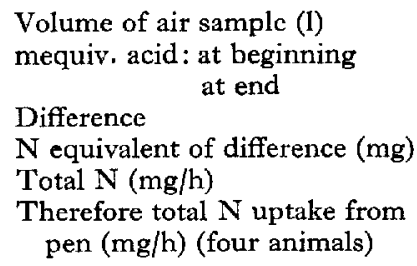

\begin{tabular}{|c|c|}
\hline Inlet air & Exhaust air \\
\hline 3460 & 3540 \\
\hline $3 \circ 0$ & $3 \cdot 0$ \\
\hline $2 \cdot 642$ & $I \cdot 490$ \\
\hline 0.358 & $1 \cdot 510$ \\
\hline $5^{\circ}$ or & $2 I \cdot I$ \\
\hline $73 \cdot 8$ & $304 \cdot 0$ \\
\hline
\end{tabular}

\section{Measurements made and analytical techniques}

Dry-matter and energy content. In each experimental period the dry matter of the food and faeces was determined by drying two 600-800 $\mathrm{g}$ samples of each in an oven at $60-70^{\circ}$ until constant weight was attained. This took about $2 \mathrm{~d}$ for food and $4 \mathrm{~d}$ for faeces. Dry-matter determinations of the food residue were made at the end of each experiment on the total residues collected throughout the experiment. The dry-matter contents of the urine and washings were determined in each experimental period by freeze-drying 100-250 ml of each period sample. After drying, the energy content of the sample was determined in an automatic adiabatic bomb calorimeter (Gallenkamp CB Iro).

From a knowledge of both dry-matter and energy content the gross energy intake of the animals and the output in faeces and urine (including washings) can be calculated. The metabolizable energy intake is then calculated on the assumption that $0.6 \%$ of the gross energy intake is lost as methane (Breirem, 1935; Verstegen, 1971). As the energy lost as heat was measured, the energy retained by the animals was calculated by subtracting the heat loss from the metabolizable energy. The following abbreviations for energy terms will be used subsequently: GE, gross energy; ME, metabolizable energy; ER, energy retention.

$N$ determinations. The $\mathrm{N}$ content of the food, food residues, faeces, urine and condensate were determined by the micro-Kjeldahl method and the digested samples were subsequently analysed on an AutoAnalyzer (Technicon no. I, Sampler no. II; Technicon Instruments Co. Ltd, Basingstoke, Hants) and compared with a standard reference made from ammonium sulphate.

Any hair and skin debris shed from the animals were gathered in the faeces and washings, and their $\mathrm{N}$ content was therefore included in the estimation. The total $\mathrm{N}$ retention is given by the difference between the $\mathrm{N}$ content of the food on the one side, and on the other side that of the urine, faeces, washings and food residue, and as $\mathrm{NH}_{3}$ 
Table 3. Metabolizable energy intake, heat loss, energy retention and deposition of protein and fat, expressed as $(A) \mathrm{kf}$ per $\mathrm{kg}$ body-weight per $d$ and $(B) \mathrm{kJ}$ per unit metabolic body size $\left(\mathrm{kg}^{0 \cdot 75}\right)$ per $d$, in groups of pigs at different environmental temperatures and different levels of feeding

\begin{tabular}{|c|c|c|c|c|c|}
\hline Treatment: temperature $\left({ }^{\circ} \mathrm{C}\right)$ & & & & & \\
\hline $\mathrm{g}$ food/kg body-wt per d & 39 & 45 & 45 & 52 & treatment mean \\
\hline $\begin{array}{l}\text { Metabolizable energy } \\
\text { A } \\
\text { B }\end{array}$ & $\begin{array}{r}468 \\
\times 104\end{array}$ & $\begin{array}{r}536 \\
.1265\end{array}$ & $\begin{array}{r}543 \\
1286\end{array}$ & $\begin{array}{r}618 \\
1464\end{array}$ & $\begin{array}{r}7 \\
21\end{array}$ \\
\hline $\begin{array}{c}\text { Heat loss } \\
\text { A } \\
\text { B }\end{array}$ & $\begin{array}{l}276 \\
651\end{array}$ & $\begin{array}{l}297 \\
699\end{array}$ & $\begin{array}{l}330 \\
783\end{array}$ & $\begin{array}{l}335 \\
792\end{array}$ & $\begin{array}{r}8 \\
18\end{array}$ \\
\hline $\begin{array}{c}\text { Energy retention } \\
\text { A } \\
\text { B }\end{array}$ & $\begin{array}{l}192 \\
453\end{array}$ & $\begin{array}{l}239 \\
566\end{array}$ & $\begin{array}{l}212 \\
503\end{array}$ & $\begin{array}{l}284 \\
673\end{array}$ & $\begin{array}{r}3 \\
13\end{array}$ \\
\hline $\begin{array}{r}\text { Protein } \\
\text { A } \\
\text { B }\end{array}$ & $\begin{array}{r}71 \\
\text { I } 68\end{array}$ & $\begin{array}{r}77 \\
\text { I } 84\end{array}$ & $\begin{array}{r}85 \\
201\end{array}$ & $\begin{array}{r}90 \\
213\end{array}$ & $\begin{array}{l}3 \\
9\end{array}$ \\
\hline Fat $\begin{array}{r} \\
\text { A } \\
\text { B }\end{array}$ & $\begin{array}{l}\text { I 2 I } \\
285\end{array}$ & $\begin{array}{l}\text { I } 62 \\
382\end{array}$ & $\begin{array}{l}127 \\
302\end{array}$ & $\begin{array}{l}194 \\
460\end{array}$ & $\begin{array}{r}4 \\
10\end{array}$ \\
\hline
\end{tabular}

in the condensate and ventilating air. The protein gain of the animals can then be computed by assuming that the $\mathrm{N}$ content of protein is $16 \%$. Taking the calorific value of protein as $23.8 \mathrm{~kJ} / \mathrm{g}$, that is $5.7 \mathrm{kcal} / \mathrm{g}$ (Brouwer, 1965 ), the energy value of the protein retained can also be determined. The energy content of the fat gain may then be obtained from the difference between the total ER and the energy content of the protein gain, ignoring carbohydrate. Assuming that the fat has an energy value of 39.8 $\mathrm{kJ} / \mathrm{g}$, that is $9.5 \mathrm{kcal} / \mathrm{g}$ (Brouwer, I965), the weight of fat deposited can then be calculated.

\section{RESULTS}

Heat loss, ER and the partition of ER between protein and fat were determined from the energy and $\mathrm{N}$ balance measurements. The mean values, expressed per $\mathrm{kg}$ bodyweight and per unit of metabolic body size taken as $\mathrm{kg}^{0.75}$ (Kleiber, $196 \mathrm{I}$ ), are given in Table 3. Metabolic body size was used as a base for calculation in an attempt to normalize the variations associated with differences in body-weight; as $\mathrm{kg}^{0 \cdot 75}$ is commonly used for this purpose, results expressed in this way can be compared with results from other sources.

\section{$M E$, heat loss and $E R$}

The animals were fed according to body-weight and the correlation coefficient between ME and body-weight within experiments was $0.964-0.987$. The coefficients differed by less than 0.002 from these values when ME was related to $\mathrm{kg}^{0.75}$.

The amount of faeces produced per day varied from 2.5 to $6.5 \mathrm{~kg} / \mathrm{d}$ per four animals, depending on the feeding level and the dry-matter content of the faeces. The dry-matter content was about $24 \%$ in the $8^{\circ}$ experiments and $27-30 \%$ in the $20^{\circ}$ 


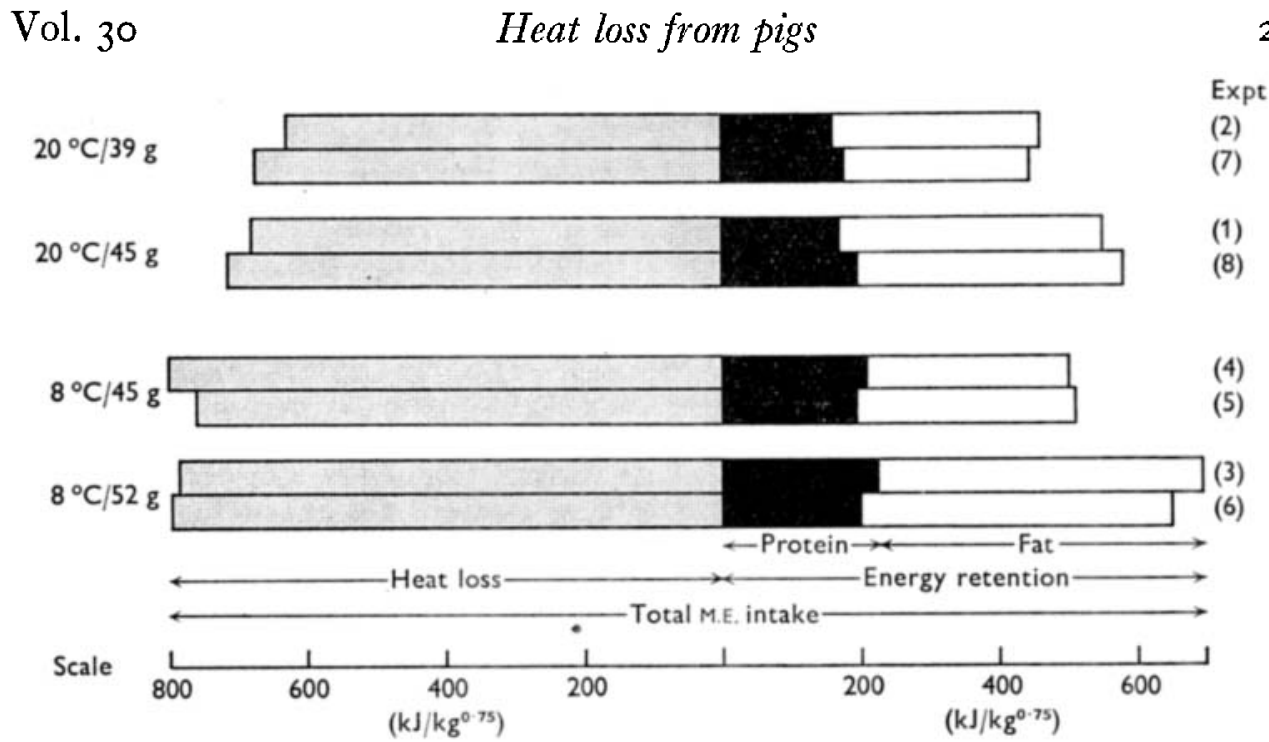

Fig. I. Partition of the metabolizable energy (ME) intake into heat loss and energy retention as protein and fat (expressed as $\mathrm{kJ} / \mathrm{kg}^{0.75}$ ) in groups of pigs on different feeding levels at ambient temperatures of $8^{\circ}$ and $20^{\circ}$.

experiments. The urine collected ranged from 8 to $201 / \mathrm{d}$ in six out of the eight experiments, and in Expts 6 and 8 it ranged from 8 to $40 \mathrm{l} / \mathrm{d}$. The faecal energy, which at $20.5 \%$ of intake accounted for the greatest part of the energy of the excreta, remained constant irrespective of the temperature or feeding level. Urinary energy losses were $\mathrm{I} \cdot 5^{-2} \cdot 7 \%$ of intake and the energy in the washings varied between $\mathbf{x} \cdot 4$ and $2 \cdot 1 \%$ of the total energy intake. Thorbek ( 1969 ), in measurements of energy metabolism in pigs ranging from 30 to $85 \mathrm{~kg}$ body-weight, found the energy loss in the urine to be $\mathrm{I} \cdot 8 \%$ of GE. Assuming that methane production in the pig is $0.6 \%$ of $\mathrm{GE}$ (Breirem, I935, I939; Verstegen, I97I), the metabolizability of the ration was $74^{\circ} \mathrm{O}-75.3 \%$ of GE. The absence of effect of either feeding level or temperature on the metabolizability is in accordance with the experiments reported by Piatkowski (1958) and Jenkinson, Young \& Ashton (1967).

The mean values for heat loss in each experiment were similar between each duplicate at each temperature and feeding level (Fig. I). Heat loss $/ \mathrm{kg}^{0.75}$ at $8^{\circ}$ was, on average, $16 \%$ higher than that at $20^{\circ}$ and independent of the plane of nutrition. At $20^{\circ}$, however, heat loss tended to be higher on the $45 \mathrm{~g}$ feeding level than it was on the $39 \mathrm{~g}$ feeding level. Although me intake increased by $\mathbf{I}_{4} .5$ and $\mathrm{x}_{3} .8 \%$ when the feeding level was raised at $20^{\circ}$ and $8^{\circ}$ respectively, heat loss increased by $7.4 \%$ at $20^{\circ}$ and by only $\mathbf{I} \cdot \mathrm{I} \%$ at $8^{\circ}$.

ER was highest on the $5^{2} \mathrm{~g}$ feeding level at $8^{\circ}$ and least on the $39 \mathrm{~g}$ fecding level at $20^{\circ}$ (Fig. I). However, on a between-temperature comparison $\mathrm{ER} / \mathrm{kg}^{0.75}$ in the animals given $45 \mathrm{~g} / \mathrm{kg}$ body-weight per $\mathrm{d}$ at $20^{\circ}$ was $12.5 \%$ higher than that on a similar food intake at $8^{\circ}$. Although the ratios of ER to ME were approximately similar, $44.6 \%$ at $20^{\circ}$ and $39.2 \%$ at $8^{\circ}$, the higher ER reflected the $10.7 \%$ decrease in heat loss at $20^{\circ}$ compared with that at $8^{\circ}$. 


\section{$N$ balance}

The errors associated with the $\mathrm{N}$ determination, expressed as the coefficient of variation, were about $\mathrm{I}-2 \%$ for the food, $2-3 \%$ for the faeces and urine, and $4-6 \%$ for the washings. The errors cited also include sampling and Kjeldahl digestion errors. Food residue, in some instances, contained some hair and skin debris so that in these instances the $\mathrm{N}$ concentration of the food residue was higher than that of the food. The washings also contained some skin and hair debris deposited underneath the wooden slats and therefore also included a higher proportion of $\mathrm{N}$. The $\mathrm{N}$ content of the washings was $3-5 \%$ of the total $\mathrm{N}$ intake, and depended on the cleanliness of the animals and the ease of removal of the faeces. The $\mathrm{N}$ contents of the faeces and urine were $19 \cdot 6-23 \cdot 2 \%$ and $25 \cdot 5-32 \cdot 1 \%$ respectively of the total $\mathrm{N}$ intake. In the air about $2-4 \%$ of the $\mathrm{N}$ intake was found to be escaping as $\mathrm{NH}_{3}$. The $\mathrm{N}$ content of the excreta showed more variation within experiments than did the energy content, but the variation between each replicated experiment was less than that between treatments.

As it was not possible to partition the $\mathrm{N}$ in the washings into its faecal and urinary components it was not possible to calculate precisely the digestibility of the $\mathrm{N}$ in the food. However, excluding the faecal $\mathrm{N}$ in the washings, the apparent digestibility of $\mathrm{N}$ varied within the narrow range $76 \cdot 7-78 \cdot 4 \%$ of the total $\mathrm{N}$ intake and seemed to be independent of both temperature and feeding level. These values are in accordance with those found by Verstegen (197r) with individual pigs wearing a harness and fed at several levels of dietary energy intake, but lower than the $80 \cdot 3-83 \cdot 6 \%$ in individual pigs found by Fuller \& Boyne (1971), who also found some change in digestibility with environmental temperature. However, Fuller \& Boyne did not measure ammonia losses to the air.

\section{$N$ retention and fat deposition}

The relations of both temperature and food intake to $\mathrm{N}$ retention are indicated in Table 4. The values are the means for each pair of experiments. For all the four treatments the retention of $\mathrm{N}$ was relatively uniform, with no significant differences.

Fat deposition varied more than protein deposition (Table 5). The mean proportions of ME deposited as fat were highest $\left(3 \mathrm{r} \cdot 4 \%\right.$ ) at $8^{\circ}$ on the $52 \mathrm{~g}$ feeding level and lowest $(23.5 \%)$ at $8^{\circ}$ on the $45 \mathrm{~g}$ feeding level with intermediate values on the $45 \mathrm{~g}(30.1 \%)$ and $39 \mathrm{~g}(26.0 \%)$ feeding levels at $20^{\circ}$. It would therefore appear that fat deposition depended both on temperature and on plane of nutrition. At the $45 \mathrm{~g}$ feeding level, fat deposition was $26 \%$ higher $(P<0.0 r)$ at $20^{\circ}$ than at $8^{\circ}$. Fat deposition at the $52 \mathrm{~g}$ feeding level at $8^{\circ}$ was significantly higher $(P<0 \circ \mathrm{O})$ than that at the $45 \mathrm{~g}$ feeding level at $8^{\circ}$. Similarly, at the $45 \mathrm{~g}$ feeding level at $20^{\circ}$ fat deposition was significantly higher $(P<0.05)$ than at the $39 \mathrm{~g}$ feeding level at $20^{\circ}$.

\section{Body-weight gain and its energy value}

The mean body-weight gains and growth rates (expressed both as $\mathrm{g} / \mathrm{d}$ and as a percentage of the mean body-weight) are presented in Table 6 . There was good agreement in proportionate growth rate between the two replicates in each treatment, 
Table 4. Nitrogen retention of groups of pigs at two environmental temperatures and three planes of nutrition

\begin{tabular}{|c|c|c|c|c|c|c|}
\hline \multirow{3}{*}{$\begin{array}{l}\text { Temperature }\left({ }^{\circ} \mathrm{C}\right) \\
\text { Plane of nutrition } \\
\text { (g food } / \mathrm{kg} \text { body-wt per } \mathrm{d})\end{array}$} & \multicolumn{4}{|c|}{ Treatment means } & \multirow{3}{*}{$\begin{array}{l}\text { Treatment } \\
\text { significance }\end{array}$} & \multirow{3}{*}{$\begin{array}{c}\text { SE of a } \\
\text { treatment } \\
\text { mean }(4 \mathrm{df})\end{array}$} \\
\hline & \multicolumn{2}{|c|}{20} & \multicolumn{2}{|r|}{8} & & \\
\hline & 39 & 45 & 45 & $5^{2}$ & & \\
\hline \multirow{2}{*}{$\begin{array}{l}\text { g/animal per } \mathrm{d} \\
\mathrm{g} / \mathrm{kg}^{0 \cdot 75} \text { per } \mathrm{d} \\
\mathrm{mg} / \mathrm{g} \mathrm{N} \text { intake }\end{array}$} & $\begin{array}{c}\mathrm{I} 4 \cdot 80 \\
\mathrm{I} \cdot \mathrm{I} 24\end{array}$ & $\begin{array}{c}16 \cdot I 7 \\
I \cdot 228\end{array}$ & $\begin{array}{l}18 \cdot 00 \\
r \cdot 35^{2}\end{array}$ & $\begin{array}{l}19.17 \\
1.430\end{array}$ & $\begin{array}{l}\text { NS } \\
\text { NS }\end{array}$ & $\begin{array}{l}\mathrm{x} \cdot 63 \\
0.063\end{array}$ \\
\hline & & 422 & 422 & 393 & NS & $22 \cdot I$ \\
\hline
\end{tabular}

Table 5. Fat deposition in groups of pigs at two environmental temperatures and three planes of nutrition

\begin{tabular}{|c|c|c|c|c|c|c|}
\hline \multirow{3}{*}{$\begin{array}{l}\text { Temperature }\left({ }^{\circ} \mathrm{C}\right) \\
\text { Plane of nutrition } \\
(\mathrm{g} \text { food } / \mathrm{kg} \text { body-wt per } \mathrm{d})\end{array}$} & \multicolumn{3}{|c|}{ Treatment means } & \multirow[b]{2}{*}{8} & \multirow{3}{*}{$\begin{array}{l}\text { Treatment } \\
\text { significance }\end{array}$} & \multirow{3}{*}{$\begin{array}{c}\text { SE of a } \\
\text { treatment } \\
\text { mean }(4 \mathrm{df})\end{array}$} \\
\hline & \multicolumn{2}{|c|}{20} & & & & \\
\hline & 39 & 45 & 45 & 52 & & \\
\hline $\begin{array}{l}\text { g/animal per d } \\
\mathrm{g} / \mathrm{kg}^{0 \cdot 75} \text { per } \mathrm{d} \\
\mathrm{mg} / \mathrm{g} \text { food intake }\end{array}$ & $\begin{array}{l}94 \cdot 6 \\
7 \cdot 19 \\
79 \cdot 3\end{array}$ & $\begin{array}{l}\text { I26.5 } \\
9 \cdot 58 \\
92 \cdot 1\end{array}$ & $\begin{array}{l}102 \cdot 2 \\
7 \cdot 59 \\
72 \cdot 2\end{array}$ & $\begin{array}{l}\mathbf{1} 55^{\cdot 9} \cdot \\
1 \mathbf{1} \cdot 56 \\
95^{\circ} \cdot 0\end{array}$ & $\stackrel{*}{* * *}$ & $\begin{array}{l}8.40 \\
0.25 \\
2.59\end{array}$ \\
\hline
\end{tabular}

Table 6. Rate of body-weight gain, water intake, energy value and composition of body-weight gain in groups of pigs

Temperature $\left({ }^{\circ} \mathrm{C}\right)$

Plane of nutrition

( $\mathrm{g}$ food $/ \mathrm{kg}$ body-wt per $\mathrm{d}$ )

Body-wt gain

(g/animal per d)

Body-wt gain

(as \% of body-wt)

$\mathrm{g}$ protein deposited/kg

body-wt gain

$\mathrm{g}$ fat deposited/kg body-wt gain

Wt of protein and fat as percentage of body-wt gain

Energy value of body-wt gain $(\mathrm{kJ} / \mathrm{g})$

Water intake $(1 / \mathrm{kg}$ bodywt per d)

Water content of gain (g/animal per d)

Water as $\%$ of protein and water

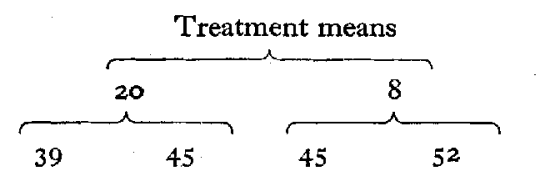

Treatment significance

SE of a treatment mean (4df)

$\begin{array}{cccccc}477.5 & 545.0 & 584.0 & 600.5 & \text { NS } & 56.6 \\ 1.54 & 1.75 & 1.84 & 1.88 & \text { NS } & 0.076 \\ 194.5 & 199.5 & 201.5 & 210.5 & \text { NS } & 9.63 \\ 199.5 & 250.0 & 175.5 & 271.5 & * & 16.7 \\ 39.40 & 44.95 & 37.70 & 48.20 & \text { NS } & 2.24 \\ 12.60 & 13.75 & 11.80 & 15.80 & * & 0.61 \\ 0.128 & 0.222 & 0.122 & 0.220 & \text { NS } & 0.058 \\ 243.0 & 282.0 & 311 \cdot 0 & 265.0 & \text { NS } & 31 \cdot 0 \\ 72.0 & 71.5 & 72.1 & 65.4 & \text { NS } & 2.2\end{array}$

NS, not significant; $* P<0.05$. 
with differences not exceeding I $1 \%$. The mean proportionate growth rate was highest among the pigs on $5^{2} \mathrm{~g}$ food $/ \mathrm{kg}$ at $8^{\circ}$, being $\mathrm{r} \cdot 88 \%$ of the mean body-weight. The growth rates of the two series with $45 \mathrm{~g}$ of food $/ \mathrm{kg}$ animal per d were $\mathrm{I} \cdot 84 \%$ at $8^{\circ}$ and $\mathrm{I} \cdot 75 \%$ at $20^{\circ}$. The animals on the $39 \mathrm{~g}$ feeding level at $20^{\circ}$ exhibited the lowest growth rate, $1 \cdot 54 \%$ of mean body-weight. The energy content of the body-weight gain was lower at the lower temperature at the same plane of nutrition, and this was associated with the lower rate of fat deposition at $8^{\circ}$. As the protein content of the gain was relatively uniform in all experiments, the difference in the energy content of the gain represents the change in fat deposition.

\section{Other measurements}

Water intake varied between 0.110 and $0.1451 / \mathrm{kg}$ body-weight and between 2.47 and $3.67 \mathrm{l} / \mathrm{kg}$ food in most experiments except for Expts 6 and 8. These values are similar to those found earlier by Mount, Holmes, Close, Morrison \& Start (1971). In Expts 6 and 8 the mean water intakes of the animals were 0.303 and $0.3001 / \mathrm{kg}$ bodyweight and 5.88 and $6.57 \mathrm{l} / \mathrm{kg}$ food respectively. The factors associated with the higher water intakes in Expts 6 and 8 could not be identified.

The mean values of rectal temperature during the experiments fell within the range $39 \cdot 2 \pm 0 \cdot 4^{\circ}$.

\section{DISCUSSION}

\section{Heat loss and $E R$}

The rates of heat loss and ER in these experiments were similar to those found in earlier investigations (Holmes \& Mount, 1967; Close et al. 1971; Verstegen, 1971). Results obtained at several feeding levels both from these earlier experiments and from the present work have been expressed per unit of metabolic body size $\left(\mathrm{kg}^{0.75}\right)$ and are given in Fig. 2. The similarity between the duplicates in the present work and their accordance with the earlier results suggest that these values provide a satisfactory basis for the prediction of the effects of environmental temperature on groups of pigs under these conditions.

The results of the present experiments show that at $8^{\circ}$ both the 45 and $52 \mathrm{~g} / \mathrm{kg}$ feeding levels are associated with similar heat losses. This accords with evidence that at this temperature both groups of pigs were below the zone of thermal neutrality, so that heat loss was determined primarily by the environment and not by the feeding level (Close et al. 197 I). ER at $8^{\circ}$ at the $45 \mathrm{~g}$ feeding level was reduced relative to that at the $52 \mathrm{~g}$ feeding level as a result of the similar environmental demands.

\section{Partial efficiency of retention of energy}

The animals on both the 39 and $45 \mathrm{~g}$ feeding levels at $20^{\circ}$ were above the critical temperature; the critical temperature is the temperature at the lower end of the zone of thermal neutrality. The difference between the two feeding levels expressed as kJ $\mathrm{ME} / \mathrm{kg}^{0.75}$ can then be related to the differences between the two rates of retention of energy $\left(\mathrm{kJ} \mathrm{ER} / \mathrm{kg}^{0.75}\right)$ in order to determine the partial efficiency of retention under 


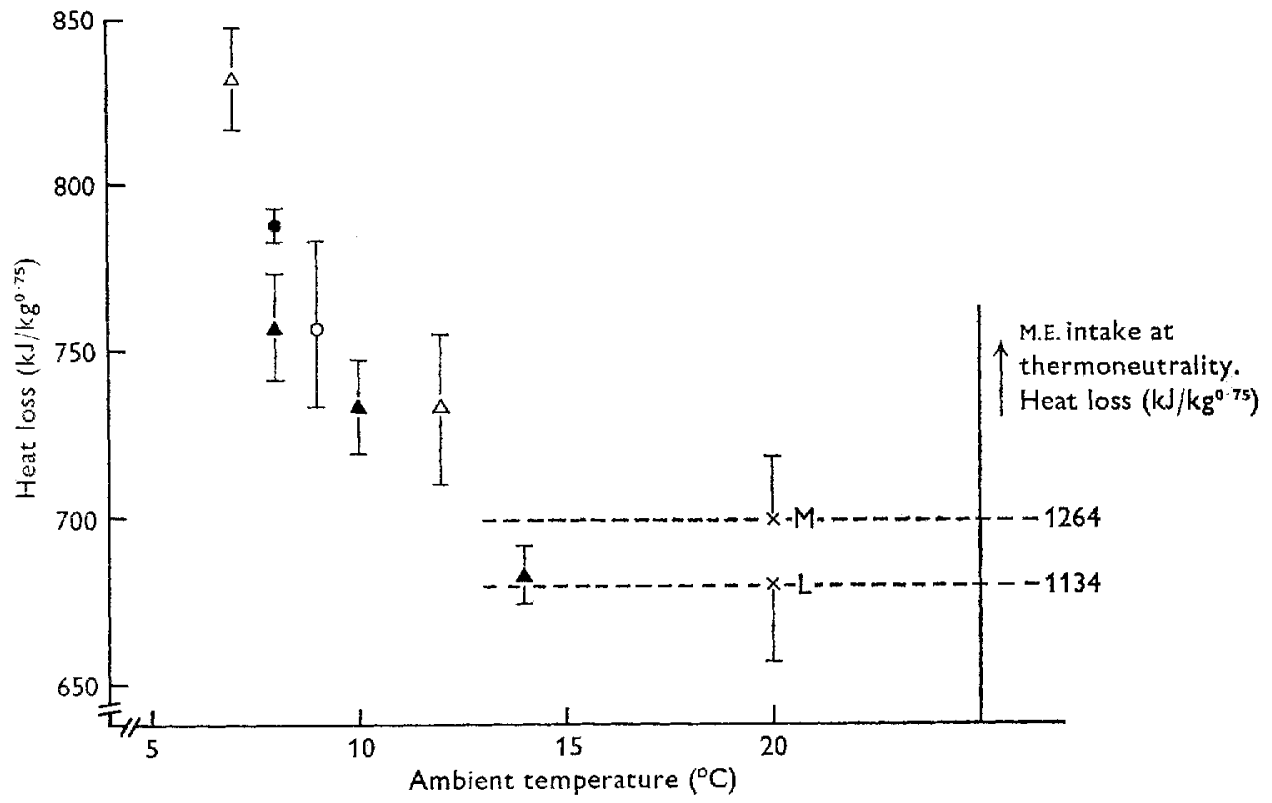

Fig. 2. Rates of heat loss from groups of pigs at several feeding levels and ambient temperatures, taken from several authors: 0 , present results; $\boldsymbol{\Delta}$, Verstegen (197I); $\Delta$, Close (1970); 0 , Holmes (I 966); $M$, mean metabolizable energy (ME) intake $1264 \mathrm{~kJ} / \mathrm{kg}^{0 \cdot 75}$.d from Verstegen (197I), Close (1970), and present results; L, mean ME intake II $34 \mathrm{~kJ} / \mathrm{kg}^{0.75} . \mathrm{d}$ from Verstegen (1971), Close (1970), Holmes (1966) and present results. The vertical bars represent the standard errors of the mean.

conditions of thermal neutrality. In using the results of all four experiments at $20^{\circ}$ and regressing $\mathrm{ER} / \mathrm{kg}^{0.75}$ on $\mathrm{ME} / \mathrm{kg}^{0.75}$ an efficiency coefficient of 0.665 was found:

$$
\mathrm{ER} / \mathrm{kg}^{0.75}=0.665( \pm 0.04) \mathrm{ME} / \mathrm{kg}^{0.75}-278( \pm 23) \text {. }
$$

If the ME above maintenance is assumed to be converted into ER with a constant efficiency at each feeding level the maintenance energy requirement $\left(\mathrm{ME}_{\mathrm{m}}\right)$ is obtained when $\mathrm{ER}=0$ in equation ( $\mathrm{I}$ ), giving $\mathrm{ME}_{\mathrm{m}}$ of $4 \mathrm{I} 8 \mathrm{~kJ} / \mathrm{kg}^{0.75}\left(100 \mathrm{kcal} / \mathrm{kg}^{0.75}\right)$ at $20^{\circ}$. From other calorimetric studies on the growing pig the maintenance energy requirements of animals of a mean body-weight similar to those used in the present experiments have been computed.

Assuming an approximate partial efficiency of conversion of ME into ER of $0^{\circ} 7$, as used by several workers, in $\mathrm{kJ} / \mathrm{kg}^{0.75}$ these estimates were $45^{2}$ (Breirem, 1935 ), 515 (Lund, 1938), 435 (Ludvigsen \& Thorbek, 1955), 515 (Verstegen, 1971), and $45^{6}$ in the present experiments (instead of the 418 which results from an efficiency of 0.665 ). The mean of all five values is $475 \mathrm{~kJ} / \mathrm{kg}^{0} \cdot 75$, and the relatively small deviations between the results indicate that this figure provides at present probably the best estimate of the pig's maintenance requirement.

At $8^{\circ}$ the regression equation relating $\mathrm{ER}$ to $\mathrm{ME}$ intake was

$$
\mathrm{ER} / \mathrm{kg}^{0.75}=0.994( \pm 0.04) \mathrm{ME} / \mathrm{kg}^{0.75}-779\left( \pm 5^{2}\right) \text {. }
$$

This means that an increase in ME intake of $\mathrm{I} k J$ results in a $0.99 \mathrm{~kJ}$ increase in ER. Ideally, a partial efficiency of unity would be expected below the critical temperature 
Table 7. Metabolizable energy required for production $\left(\mathrm{ME}_{\mathrm{p}}\right)$ and the extra environmental demand $\left(\mathrm{ME}_{8}-\mathrm{ME}_{\mathrm{m}}\right)$ of the pigs at an environmental temperature of $8^{\circ}$, above that at thermal neutrality

\begin{tabular}{|c|c|c|c|c|}
\hline Temperature $\left({ }^{\circ} \mathrm{C}\right)$ & & & & \\
\hline $\begin{array}{l}\text { Plane of nutrition } \\
\text { (g/kg body-wt per d) }\end{array}$ & & & & \\
\hline Expt no. & 4 & 5 & 3 & 6 \\
\hline ME intake/kg0*75 $(\mathrm{kJ})$ & I305 & I 268 & 1480 & I 449 \\
\hline Energy retention $/ \mathrm{kg}^{0 \cdot 75}(\mathrm{~kJ})$ & 499 & 508 & 694 & 652 \\
\hline $\mathrm{ME}_{\mathrm{p}} / \mathrm{kg}^{0.75}(\mathrm{~kJ})$ & 750 & 765 & 1044 & 980 \\
\hline $\mathrm{ME}_{8} / \mathrm{kg}^{0.75}(\mathrm{~kJ})$ & 555 & 503 & 437 & 469 \\
\hline $\begin{array}{l}\text { Extra } \mathrm{ME} / \mathrm{kg}^{0 \cdot 75} \text { for thermogenesis } \\
\text { at } 8^{\circ *}(\mathrm{~kJ})\end{array}$ & 137 & 85 & I 8 & 50 \\
\hline
\end{tabular}

since increased food intake is not associated with an increase in heat loss under those conditions; the energy dissipated in association with protein and fat retention spares some of the animal's heat production which is being stimulated by the thermoregulatory demand of the cold environment. The extra thermoregulatory heat production due to the cold environment can be calculated as follows. As the energy retention is known, the $\mathrm{ME}$ which is involved $\left(\mathrm{ME}_{\mathrm{p}}\right)$ to cover both the retained material and the extra heat production associated with retention is obtained by dividing ER by the efficiency calculated for thermal neutrality, that is the figure of 0.665 found at $20^{\circ}$. Subtracting $\mathrm{ME}_{\mathrm{p}}$ from the total $\mathrm{ME}$ intake gives the $\mathrm{ME}$ required for maintenance at thermal neutrality plus the extra environmental demand at $8^{\circ}\left(\mathrm{ME}_{8}\right)$. Subtracting the maintenance requirement at thermal neutrality $\left(418 \mathrm{~kJ} / \mathrm{kg}^{0} \cdot 75\right)$ from $\mathrm{ME}_{8}$ gives the $\mathrm{ME}$ which is used for the extra thermoregulatory heat production; this is additional to the total heat production at $20^{\circ}$, including the heat production which is associated with retention of energy and which has to be dissipated at $20^{\circ}$, although at $8^{\circ}$ it serves a thermoregulatory function. If the efficiency at $8^{\circ}$, that is 0.994 (equation 2) were used in the calculation, the heat production associated with retention would be excluded from the $\mathrm{ME}_{\mathrm{p}}$ term, and would appear instead as extra thermoregulatory heat, which it is not. Table 7 shows that in all experiments carried out at $8^{\circ}$ the animals used part of ME for extra thermoregulatory heat production and consequently all the groups at $8^{\circ}$ were below the critical temperature.

Verstegen (1971) found that six groups of four animals $(20-5 \circ \mathrm{kg}$ ) produced on average $I I \cdot 3 \mathrm{~kJ} / \mathrm{kg}^{0} \cdot 75$ extra heat per ${ }^{\circ} \mathrm{C}$ below the critical temperature. Applying this finding in these experiments means that the critical temperature of animals on the $52 \mathrm{~g}$ feeding level was about $10-1 \mathrm{I}^{\circ}$ and that of the animals on the $45 \mathrm{~g}$ feeding level about $16-17^{\circ}$, results which are in accordance with the estimates of critical temperature made by Verstegen (1971). Close et al. (197I) found from their groups of pigs that a rate of energy retention similar to that at $12^{\circ}$ could be maintained at $7^{\circ}$ by giving an extra $6.5 \mathrm{~g}$ food $/ \mathrm{kg}$ body-weight $(67.0 \mathrm{~kJ} \mathrm{ME})$ per $\mathrm{d}$. They found similar ER at 12 and $20^{\circ}$ on 
the same feeding level, and assumed $12^{\circ}$ as the critical temperature. Fig. 2 suggests that the critical temperature is in this region on the higher feeding levels, but that it is raised, as expected, when the feeding level is lower.

In the present experiments I $\mathrm{g}$ of food contained I2:० $\mathrm{kJ} \mathrm{ME}$. Below the apparent critical temperature, ER increases by $0.99 \mathrm{~kJ}$ per kJ increase in ME intake (equation 2). From the results given in Table 7 , in order to maintain a similar ER at $8^{\circ}$ and $20^{\circ}$ and at the $45 \mathrm{~g}$ level of feeding, the animals at $8^{\circ}$ have to increase their ME intake by III $\mathrm{kJ} / \mathrm{kg}^{0.75}$ (mean values of the extra ME $/ \mathrm{kg}^{0} \cdot 75$ for thermogenesis in Expts 4 and 5). This means that III $\div 12=9.3 \mathrm{~g}$ food $/ \mathrm{kg}^{0.75}$ are required to maintain similar energy retentions at $8^{\circ}$ and $20^{\circ}$. When expressed per $\mathrm{kg}$ for a mean body-weight of $30 \mathrm{~kg}$ this represents an increase of $3.9 \mathrm{~g}$ food $/ \mathrm{kg}$ body-weight. On the assumption that the apparent critical temperature at the $45 \mathrm{~g}$ feeding level is $16^{\circ}$, this represents an increased food intake of $0.5 \mathrm{~g}$ food per ${ }^{\circ} \mathrm{C}$ decrease below the apparent critical temperature per $\mathrm{kg}$ body-weight per $\mathrm{d}$. By assuming the same apparent critical temperature in the experiments of Close et al. (197I), food intake would have to be increased by $0.7 \mathrm{~g}$ per $\mathrm{kg}$ body-weight per $\mathrm{d}$ per ${ }^{\circ} \mathrm{C}$ fall in temperature below the apparent critical temperature. On their assumption of a critical temperature of $12^{\circ}$ the corresponding value was $\mathrm{I} \cdot 3 \mathrm{~g} / \mathrm{kg}$ per ${ }^{\circ} \mathrm{C}$ per $\mathrm{d}$.

It is therefore important that the apparent critical temperature on a given feeding level should be assessed, first to determine whether extra thermoregulatory heat production is demanded by the particular environment, and second to arrive at the probable additional food needed to maintain a given level of energy retention if the animals are below their critical temperature.

\section{Protein and fat deposition}

$\mathrm{N}$ retention expressed per $\mathrm{g} \mathrm{N}$ intake did not differ significantly between temperature and feeding levels (Table 4), so that the higher food intake resulted in a higher $\mathrm{N}$ retention. When $N$ retention was regressed on food intake it increased by $9.98( \pm 0.8)$ $\mathrm{mg} \mathrm{N} / \mathrm{g}$ food increase (correlation coefficient 0.94 ). Weight gain showed a pattern similar to that of $\mathrm{N}$ retention and the correlation between $\mathrm{N}$ retention and weight gain was also 0.94 . The magnitude of the increase in $\mathrm{N}$ balance with increase in feeding level in the present experiments was similar to that reported by Fuller \& Boyne (1971), who found an increase of $165 \mathrm{mg} N$ per increment of I $\mathrm{g}$ food $/ \mathrm{kg}^{0.75}$ in animals weighing $55 \mathrm{~kg}$, equivalent to $8.5 \mathrm{mg} \mathrm{N} / \mathrm{g}$ food.

Whereas $\mathrm{N}$ retention per unit of ME intake was independent of either temperature or feeding level, fat deposition was more variable and depended on both these factors. At a similar level of food intake fat deposition was reduced by $21 \%$ at $8^{\circ}$ compared with that at $20^{\circ}$, representing a difference of $34.3 \mathrm{~kJ}$ fat $/ \mathrm{kg}$ body-weight (Table 5). Fuller (1965) also found that the deposition of fat was significantly affected by temperature; the highest deposition occurred at $25^{\circ}$, which also approximated to the highest rate of gain recorded in his experiments. Piatkowski (1958) and Sørensen (1962) suggested that pigs produced fatter carcasses in the cold; in these observations the pigs were in the body-weight range in which the rate of deposition of fat would be expected to be faster than that of protein (Oslage \& Fliegel, 1965). From indirect 
calculation, Close \& Mount (I97I) concluded that both protein and fat depositions were reduced in the cold compared with the warm, although when the feeding level was reduced in the cold the fat deposition was reduced to a much greater extent than that of protein. From their results, Fuller \& Boyne (197I) concluded that, whereas slow growth rate achieved by a reduction in food intake is associated with a decreased fatness, that produced by cold is not. In the present experiments, however, fatness was also decreased in the cold with pigs on the restricted food intake of $45 \mathrm{~g} / \mathrm{kg}$ per d, although at the higher feeding level of $5^{2} \mathrm{~g}$ at $8^{\circ}$ fat deposition was the highest for the four treatments.

\section{Growth rate}

The rate of body-weight gain was decreased by 10 and $3 \%$ at 20 and $8^{\circ}$ respectively when the feeding levels were reduced. When compared on a between-temperature basis, however, the body-weight gain at the $45 \mathrm{~g} / \mathrm{kg}$ feeding level increased by $7 \%$ at $8^{\circ}$ compared with that at $20^{\circ}$. Although this might be contrary to expectation, it is explicable in terms of the type of gain, protein or fat, and the water retention associated with each. Although the changes in heat loss and ER were those to be expected when the temperature and feeding level were changed, the vatiation between groups associated with weight gain was probably too large for a useful comparison to be made. This implies that the variation in weight gain is largely due to variation in water content, and reference to Table 6 supports this view.

It was assumed that $3.5 \%$ of the body-weight gain was ash (Hörnicke, 1962) and that $6.5 \%$ was gutfill (Wood, 1926) and these values were subtracted from the bodyweight gain. The values for fat and protein gain were then subtracted, leaving the water retention by difference. Apart from Expt 6, the proportion of water in the combined water and protein gain did not vary much, the variation being between 69 and $74 \%$. The discrepancy between this value and that of Hörnicke (I962), who obtained a value of $79 \%$, may be due to systematic differences in the method of estimation. The protein gain, and by implication the associated water, varied relatively little between experiments, but fat deposition was closely related to both feeding level and temperature. This explains why cold conditions can influence weight gain in young animals to a smaller extent than would be expected on the basis of the extra heat loss.

We thank Mr G. Bull, Mr M. J. Bacon and Miss M. H. Hamon for assistance with analytical procedures.

\section{REFEREN CES}

Breirem, K. (1935). Beretn. Forogslab. no. 162.

Breirem, K. (1939). Tierernährung II, 437.

Brouwer, E. (1965). Publs Eur. Ass. Anim. Prod. no. I I, p. 441.

Close, W. H. (1970). Nutrition-environmental interactions of growing pigs. PhD Thesis, The Queen's University of Belfast.

Close, W. H. \& Mount, L. E. (1971). Proc. Nutr. Soc. 30, 33A.

Close, W. H., Mount, I. E. \& Start, I. B. (r971). Anim. Prod. 13, 285.

Fuller, M. F. (1965). Br. F. Nutr. 19,531.

Fuller, M. F. \& Boyne, A. W. (197I). Br. F. Nutr. 25, 259.

Graham, N. McC., Wainman, F. W., Blaxter, K. L. \& Armstrong, D. G. (1959). F. agric. Sci., Camb. 52, I 3 . 
Holmes, C. W. (1966). Studies on the effects of environment on heat losses from pigs. PhD Thesis, The Queen's University of Belfast.

Holmes, C. W. \& Mount, L. E. (1967). Anim. Prod. 9, 435.

Hörnicke, H. (1962). Z. Tierphysiol. Tierernähr. Futtermittelk. 17, 28.

Jenkinson, G. M., Young, L. G. \& Ashton, G. C. (1967). Can. F. Anim. Sci. 47, 2 I7.

Kleiber, M. (196r). The Fire of Life. New York: Wiley.

Livingston, D. M. S., Fuller, M. F. \& Livingstone, R. M. (1969). Anim. Prod. rr, 55.

Ludvigsen, J. \& Thorbek, G. (1955). Beretn. Forøgslab. no. 283.

Lund, A. (1938). Beretn. Forøgslab. no. 180.

Mount, L. E., Holmes, C. W., Close, W. H., Morrison, S. R. \& Start, I. B. (1971). Anim. Prad. 13, 56r.

Mount, L. E., Holmes, C. W., Start, I. B. \& Legge, A. J. (Ig67). \%. agric. Sci., Camb. 68, 47.

Oslage, H. J. \& Fliegel, H. (1965). Publs Eur. Ass. Anim. Prod. no. I1, p. 297.

Piatkowski, B. (1958). Arch. Tierernähr. 8, I61.

Sørensen, P. H. (1962). In Nutrition of Pigs and Poultry p. 88 [J. T. Morgan and D. H. Lewis, editors]. London: Butterworths.

Thorbek, G. C. (1969). Publs Eur. Ass. Anim. Prod. no. 12, p. 28 I.

Verstegen, M. W. A. (197I). Meded. LandbHogesch., Wageningen 71-2.

Wood, T. B. (1926). F. agric. Sci., Camb. 16, 425 . 